\title{
Compliance Pengguna Antihipertensi di RSUP DR. SARDJITO Yogyakarta (Periode Juli 2006- Juni 2009)
}

\author{
Dimas Pramita Nugraha $^{1 *}$, Iwan Dwiprahasto ${ }^{2}$, Jarir At Thobari ${ }^{2}$
}

\begin{abstract}
Hypertension is the second largest of the 10 diseases on an outpatient at a hospital in Indonesia. The poor compliance to therapy of hypertension is a major cause of uncontrolled blood pressure. The aim of this study is to determine compliance antihypertension on patient at DR. Sardjito hospital Yogyakarta. This study was designed with a retrospective cohort study design using $a$ database of participants claimed prescribing health insurance (ASKES) in the DR. Sardjito hospital using antihypertensive drugs. Compliance measured with medication possession ratio (MPR). Data was analysed by chi- square and logistic regression statistic. From 8.011 patients, compliance of antihypertensive drugs during the first year is $7,6 \%$. Analysis for compliance showed that the type of antihypertensive diuretics are more compliance compare with angiotensin II receptor blockers, ACE inhibitors, calcium channel blockers and beta blockers. Combination therapy $(20,7 \%)$ is more compliance than monotherapy $(4,1 \%)$, as well as drugs administration 1 time a day $(8,2 \%)$ is more compliance than drug administration 2 times $(2,5 \%)$ and 3 times a day (3\%). The proportion of compliance in antihypertensive users at DR. Sardjito hospital classified as less good. Compliance pattern indicates that therapy is not continuous, the longer the use of antihypertensive therapy, the higher the discontinuous therapy.
\end{abstract}

Keywords : hypertension, antihypertension, compliance.

Menurut profil kesehatan Indonesia, penyakit hipertensi menempati urutan kedua setelah stroke dari 10 penyakit terbanyak pada pasien rawat jalan di rumah sakit yaitu sebesar 4,67\%. Riset kesehatan dasar tahun menunjukkan bahwa stroke, hipertensi, dan penyakit jantung meliputi lebih dari sepertiga penyebab kematian. Stroke menjadi penyebab kematian terbanyak $15,4 \%$, kedua hipertensi $6,8 \%$, penyakit jantung iskemik $5,1 \%$, dan penyakit jantung $4,6 \%{ }^{1}$

Compliance yang baik dalam pengobatan dapat menurunkan mortalitas dan morbiditas yang berhubungan dengan hipertensi. Dalam praktek sehari-hari penggunaan obat yang tidak tuntas, penggantian resep obat dan pemberhentian penggunaan obat merupakan hal-hal yang sering merusak konsistensi terapi. Efek yang timbul dari

\footnotetext{
1* Coresponding Author: Bagian Farmakologi Fakultas Kedokteran Universitas Riau, Pekanbaru

2 Bagian Farmakologi dan Toksikologi Fakultas Kedokteran Universitas Gadjah Mada,Yogyakarta
}

terapi yang tidak optimal berhubungan dengan progresivitas atherosklerosis pembuluh koroner, gagal jantung congestive, dan penyakit ginjal yang merupakan penyebab-penyebab utama untuk terjadinya krisis hipertensi dan hospitalisasi. ${ }^{2}$

Tujuan penelitian ini adalah untuk mengetahui apakah proporsi compliance pengguna antihipertensi di RSUP DR. Sardjito Yogyakarta tergolong baik ( $\geq 80 \%$ ) dan bagaimanakah pola compliancenya. Apabila besar proporsi dan pola compliance pengguna antihipertensi dapat diketahui diharapkan dapat digunakan sebagai masukan untuk klinisi dalam menerapkan pola manajemen penggunaan antihipertensi yang lebih compliance sehingga tercapai tujuan terapi untuk menurunkan mortalitas dan morbiditas.

\section{METODE}

Rancangan penelitian ini adalah cohort retrospective dengan menggunakan claimed 
prescribing database pada peserta Asuransi Kesehatan (ASKES) di RSUP DR. Sardjito yang menggunakan obat antihipertensi. Compliance di ukur dengan menggunakan medication possession ratio (MPR) yaitu : ${ }^{3}$

Jumlah hari prescription refills

Jumlah hari yang diperlukan untuk pengobatan

Analisis compliance dikategorikan dalam 2 kelompok yaitu compliance (MPR $\geq 80 \%$ ) dan tidak compliance $(\mathrm{MPR}<80 \%)$. Kriteria inklusi pada penelitian ini adalah semua pasien yang menggunakan antihipertensi dan berumur di atas 18 tahun (telah masuk kriteria orang dewasa), menggunakan salah satu diantara 5 jenis antihipertensi ACE inhibitor, beta blocker, ,calcium channel blocker, angiotensin II receptor blocker, dan diuretik, serta merupakan pasien baru (semua pasien yang baru mendapatkan terapi dengan obat antihipertensi dan enam bulan sebelumnya belum pernah mendapatkan terapi).

Pada penelitian ini variabel bebas terdiri usia, jenis kelamin, jenis antihipertensi, monoterapi, terapi kombinasi, dan frekuensi pemberian obat. Variabel terikat adalah compliance. Data diperoleh melalui database ASKES berupa data rawat jalan dari bulan juli 2006 sampai dengan Juni 2009, pasien yang menggunakan antihipertensi.

Hasil penelitian dianalisis menggunakan analisis bivariat chi-square untuk membandingkan kelompok compliance (compliance vs tidak compliance). Regressi logistik multivariat digunakan untuk mengetahui faktor-faktor yang mempengaruhi compliance.

\section{HASIL}

Berdasarkan database ASKES jumlah data awal yang diperoleh sebanyak 153.210 data (19.939 pasien). Setelah dilakukan seleksi berdasarkan kriteria inklusi diperoleh 35.852 data (8.011 pasien). Dari 8.011 subjek penelitian sebagian besar subjek berusia $\geq 50$ tahun dengan proporsi jumlah wanita sebanding dengan pria. Jenis antihipertensi yang paling banyak digunakan oleh subjek adalah jenis ACE inhibitor diikuti oleh calcium channel blocker, angiotensin II receptor blocker, beta blocker, dan diuretik. Sebagian besar subjek mendapatkan antihipertensi monoterapi, dan umumnya dengan frekuensi pemberian obat 1 kali sehari (tabel 1).

Tabel 1. Karakteristik subjek pengguna antihipertensi

\begin{tabular}{|c|c|}
\hline Karakteristik & $\begin{array}{c}\text { Jumlah (\%) } \\
\mathrm{N}=8.011\end{array}$ \\
\hline \multicolumn{2}{|l|}{ Usia: } \\
\hline$-\quad \geq 50$ tahun & $6.286(78,5)$ \\
\hline$-\quad<50$ tahun & $1.725(21,5)$ \\
\hline \multicolumn{2}{|l|}{ Jenis kelamin : } \\
\hline - Wanita & $4.168(52,0)$ \\
\hline - Pria & $3.843(48,0)$ \\
\hline \multicolumn{2}{|l|}{ Jenis antihipertensi (\#): } \\
\hline - ACE inlibitor & $4.833(60,3)$ \\
\hline$-\mathrm{CCB}$ & $2.612(32,6)$ \\
\hline - $\mathrm{ARB}$ & $1.540(19,2)$ \\
\hline - Betablocker & $567(7,1)$ \\
\hline - Diuretik & $141(1,8)$ \\
\hline \multicolumn{2}{|l|}{ Jenis terapi } \\
\hline - Monoterapi & $6.302(78,7)$ \\
\hline - Kombinasi & $1,709(21,3)$ \\
\hline \multicolumn{2}{|l|}{ Frekuensi pemberian obat: } \\
\hline - 1 kali sehari & $7.222(90,2)$ \\
\hline - 2 kali sehari & $552(6,9)$ \\
\hline - 3 kali sehari & $237(3,0)$ \\
\hline
\end{tabular}


Hasil analisis bivariat dengan chi-square (Tabel 2) menunjukkan bahwa dari 7,6\% subjek yang compliance, kelompok pasien berusia $<50$ tahun menunjukkan kecenderungan lebih tidak compliance dibandingkan kelompok pasien berusia $\geq 50$ tahun. Tidak ada perbedaan yang bermakna antara compliance pria dibandingkan wanita. Pasien yang menggunakan monoterapi cenderung lebih tidak compliance daripada kombinasi.
Calcium channel blocker dan beta blocker walaupun memiliki proporsi compliance yang lebih besar daripada diuretik tetapi tidak bermakna secara statistik, sedangkan ARB dan ACE inhibitor cenderung lebih tidak compliance dibandingkan diuretik. Frekuensi pemberian obat 2 kali sehari dan 3 kali sehari menunjukkan kecenderungan lebih tidak compliance dibandingkan frekuensi pemberian 1 kali sehari, dan 3 kali sehari.

Tabel 2. Analisis bivariat compliance penggunaan antihipertensi

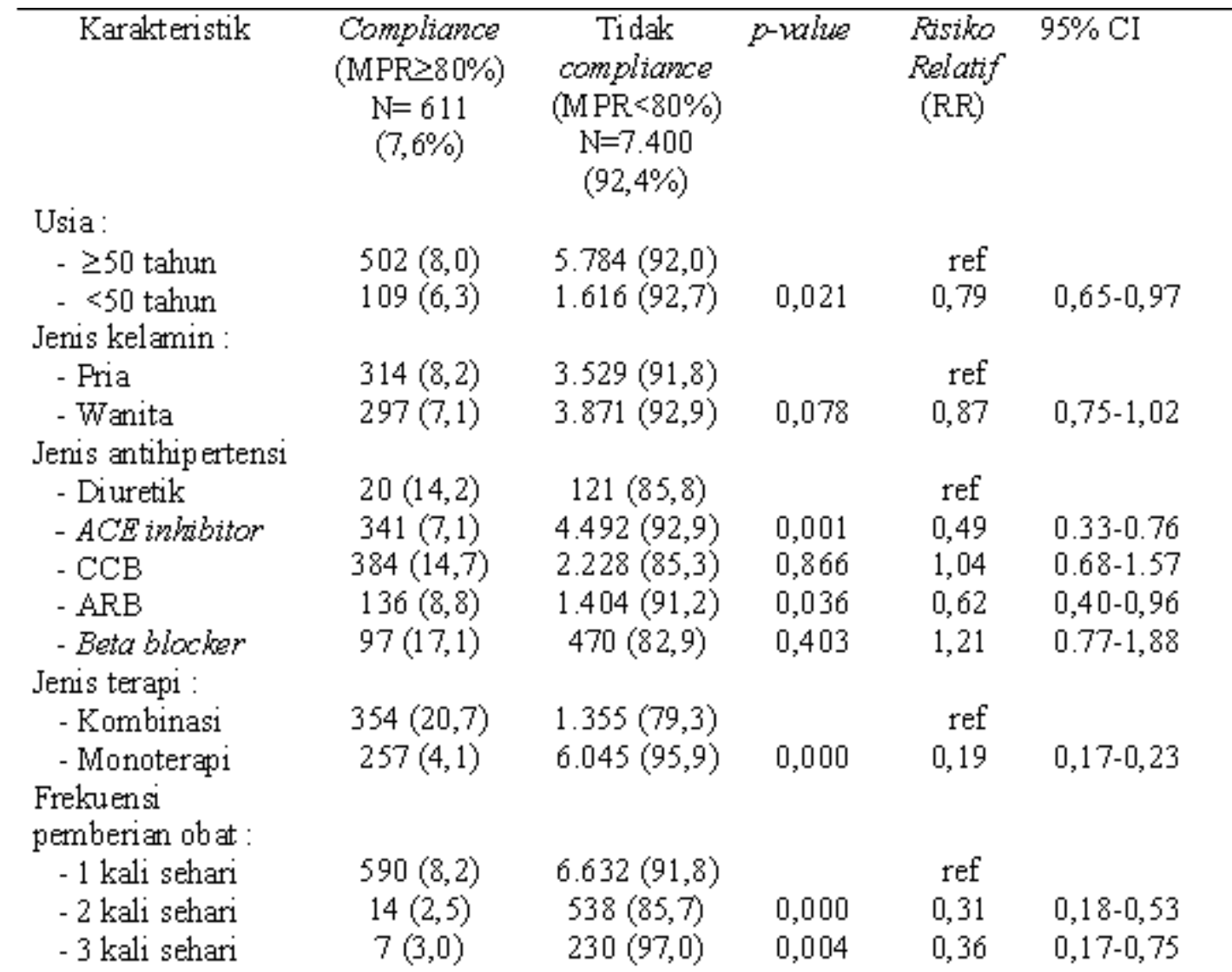

Kemudian sesudah dilakukan analisis multivariat menunjukkan bahwa monoterapi lebih tidak compliance daripada kombinasi, dan frekuensi pemberian obat 2 kali dan 3 kali sehari cenderung lebih tidak compliance daripada frekuensi pemberian obat 1 kali sehari (tabel 3). 
Tabel 3. Analisis multivariat compliance penggunaan antihipertensi

\begin{tabular}{|c|c|c|c|c|c|}
\hline \multicolumn{2}{|c|}{ Karakteristik } & $\begin{array}{c}\mathrm{RR} \\
\text { unadjusted }\end{array}$ & $95 \% \mathrm{CI}$ & $\begin{array}{c}\mathrm{RR} \\
\text { Adjusted }\end{array}$ & $95 \% \mathrm{CI}$ \\
\hline \multicolumn{6}{|c|}{ Jenis terapi : } \\
\hline - Kombi & nasi & ref & & ref & \\
\hline - Monot & Erapi & 0,19 & $0,17-0,23$ & 0,22 & $0,18-0,27$ \\
\hline \multicolumn{6}{|c|}{ Frekuensi } \\
\hline pemberian & & ref & & ref & \\
\hline-1 & $\mathrm{kali}$ & 0,31 & $0,18-0,53$ & 0,53 & $0,31-0,92$ \\
\hline sehari & & 0,36 & $0,17-0,75$ & 0,43 & $0,19-0,93$ \\
\hline $\begin{array}{ll}- & 2 \\
& \text { sehari }\end{array}$ & kali & & & & \\
\hline $\begin{array}{ll}- & 3 \\
& \text { sehari }\end{array}$ & kali & & & & \\
\hline
\end{tabular}

Analisis chi-square dan regresi logistik menunjukkan bahwa tidak ada variabel hipotesis yang dapat menjadi faktor prediktor compliance penggunaan antihipertensi, variabel pembanding menunjukkan lebih compliance daripada variabel yang dibandingkan. Hasil ini menunjukkan bahwa jenis antihipertensi diuretik, terapi kombinasi dan frekuensi pemberian obat 1 kali sehari merupakan faktor prediktor untuk compliance pada peserta pengguna antihipertensi di RSUP DR. Sardjito Yogyakarta.

\section{PEMBAHASAN}

Hasil penelitian ini menunjukkan bahwa besarnya compliance pengguna antihipertensi di RSUP DR. Sardjito Yogyakarta adalah 7,6\%. Jika kita bandingkan tingkat compliance penelitian ini dengan tingkat persistence dan compliance di Amerika dan Eropa (3478\%), maka persistence dan compliance pada penelitian ini sangatlah rendah. ${ }^{4}$

Hasil penelitian menunjukkan bahwa selama periode penelitian, pasien yang berusia $<50$ tahun cenderung lebih tidak compliance dibandingkan pasien berusia $\geq 50$ tahun. Kecenderungan pasien berusia $\geq 50$ tahun lebih persistence dan compliance ini mungkin terjadi oleh karena adanya dukungan keluarga terhadap pasien yang berusia tua untuk kontinyu dan taat dalam memakan. Penelitian Kim et al. (2002), Senior et al. (2004), dan Hertz et al. (2005) menunjukkan bahwa pasien berusia lebih tua memiliki compliance yang lebih baik dibandingkan usia muda. ${ }^{5,6,7}$

Penelitian lain memiliki hasil yang berbeda. Pada penelitian yang lain menunjukkan bahwa pasien yang lebih muda memiliki tingkat compliance yang lebih tinggi. Berdasarkan penelitian ini pasien berusia tua kemungkinan memiliki masalah dalam penglihatan, pendengaran dan memori sehingga lebih sulit mengikuti instruksi terapi dari dokter dibandingkan pasien yang lebih muda. ${ }^{8-11}$

Penelitian ini menunjukkan bahwa tidak ada perbedaan yang bermakna tingkat compliance kelompok pria dibandingkan wanita. Sebagian peneliti mengatakan bahwa jenis kelamin pria lebih tinggi tingkat compliance nya dibandingkan wanita. Sedangkan menurut peneliti lain jenis kelamin perempuan lebih tinggi compliance nya daripada laki-laki. ${ }^{12-14}$

Analisis multivariat menggambarkan bahwa angiotensin II reseptor blocker, beta blocker, ACE inhibitor dan ARB cenderung lebih tidak compliance daripada diuretik. Kemungkinan hal ini dipengaruhi oleh fakta bahwa diuretik lebih sedikit memiliki efek samping di bandingkan ARB, ACE inhibitor, beta blocker dan CCB. Hasil ini sesuai dengan guideline penatalaksanaan hipertensi dari JNC VII bahwa diuretik merupakan terapi hipertensi pilihan pertama. Walaupun demikian ada beberapa penelitian yang menunjukkan hasil yang berbeda yaitu ARB lebih compliance dibandingkan jenis antihipertensi yang lainnya. ${ }^{15}$

Penelitian ini menunjukkan bahwa monoterapi cenderung lebih tidak compliance dibandingkan terapi kombinasi, hal ini kemungkinan dikarenakan pasien yang menggunakan lebih dari satu jenis obat merasa penyakitnya lebih berat sehingga mereka lebih perhatian dan serius dalam memakan obatnya 
secara kontinyu dibandingkan dengan pasien yang menggunakan monoterapi yang merasa penyakitnya lebih ringan. Penelitian ini sesuai dengan penelitian Hashmi di Pakistan yang menunjukkan bahwa terapi kombinasi lebih compliance dibandingkan monoterapi yaitu $90 \%$ vs $79 \% .^{4}$

Walaupun demikian penelitian lain secara umum menunjukkan bahwa pasien yang menggunakan monoterapi lebih compliance dibandingkan kombinasi. Fakta ini dibuktikan oleh penelitian Iskedjian bahwa penelitian meta-analisis dari 8 studi menunjukkan monoterapi lebih compliance dibandingkan terapi kombinasi dengan nilai rata-rata $91,4 \%$ vs $83,2 \%$. Pasien yang menggunakan monoterapi merasa lebih mudah mengontrol dan memakan obat antihipertensi. ${ }^{16}$

Hasil penelitian ini menunjukkan bahwa frekuensi pemberian obat 2 kali dan 3 kali sehari cenderung lebih tidak compliance jika dibandingkan frekuensi pemberian obat $1 \mathrm{kali}$ sehari. Kemungkinan hal ini disebabkan pasien yang memakan obat hanya 1 kali sehari merasa lebih mudah memakan obatnya, sehingga mereka lebih patuh memakan obat. Penelitian ini sesuai dengan penelitian sebelumnya yang menunjukkan bahwa frekuensi pemberian obat 1 kali sehari dapat meningkatkan persistence dan compliance dan frekuensi pemberian obat lebih dari 2 kali sehari sulit untuk compliance. Walaupun demikian ada juga penelitian yang mengatakan tidak ada hubungan antara frekuensi pemberian obat dengan compliance. ${ }^{17-19}$

\section{KESIMPULAN}

Proporsi compliance pada peserta ASKES pengguna antihipertensi di RSUP DR. Sardjito Yogyakarta tergolong kurang baik. Pola compliance menunjukkan terapi yang tidak kontinyu, dan semakin lama hari penggunaan terapi antihipertensi maka semakin tinggi diskontinyu terapi.

\section{UCAPAN TERIMA KASIH}

Penulis mengucapkan terima kasih kepada semua pihak yang telah membantu dalam pelaksanaan penelitian ini.

\section{DAFTAR PUSTAKA}

1. Departemen Kesehatan Republik Indonesia. Profil Kesehatan Indonesia 2007. http:// www.depkes.go.id. Diakses pada 5 November 2009.

2. Jones JK, Gorkin L, Lian JF, Staffa JA, and Fletcher AP. Discontinuation of and changes in treatment after start of new courses of antihypertensive drugs: a study of a United Kingdom Population. BM J. 1995. 311: 293-5.

3. Yu YF, Nichol MB, Yu AP, and Ahn J. Persistence and Adherence of Medications for Chronic Overactive Bladder/Urinary Incontinence in the California Medicaid Program. Value in Health. 2005. 8(4) : 495-505.

4. Hashmi SK, Afridi MB, Abbas K, Sajwani RA, Saleheen D,Frossard PM, Ishaq M, Ambreen A, and Ahmad U.Factors Associated with Adherence to Anti-Hypertensive Treatment in Pakistan. Plos ONE. 2007. 2(3): 1-8

5. Kim YS, Sunwoo S, and Lee HR. Determinants of non-compliance with lipid-lowering therapy in hyperlipidemic patients. Pharmacoepidemiol Drug Saf. 2002. 11:593-600.

6. Senior V, Marteau TM, and Weinman J. Selfreported adherence to cholesterol-lowering medication in patients with familial hypercholesterolaemia: the role of illness perceptions. Cardiovasc Drugs Ther. 2004. 18:475-81.

7. Hertz RP, Unger AN, and Lustik MB. Adherence with pharmacotherapy for type 2 diabetes: a retrospective cohort study of adults with employer sponsored health insurance. Clin Ther. 2005. 27:1064-73.

8. Benner JS, Glynn RJ, and Mogun H. Long-term persistence in use of statin therapy in elderly patients. JAMA. 2002. 288:455-61.

9. Balbay O, Annakkaya AN, and Arbak P. Which patients are able to adhere to tuberculosis treatment? A study in a rural area in the northwest part of Turkey. Jpn J Infect Dis. 2005. 58:152-8.

10.Cooper C, Carpenter I, and Katona C. The AdHOC Study of Older Adults Adherence to Medication in 11 countries. Am J Geriatr Psychiatry. 2005. 13:1067-76. 
11. Okuno J, Yanagi $\mathrm{H}$, and Tomura $\mathrm{S}$. Is Cognitive Impairment a Risk Factor for Poor Compliance Among Japanese Elderly in the Community? Eur J Clin Pharmacol. 2001. 57:589-594.

12.Caspard H, Chan AK, and Walker AM. Compliance with a Statin Treatment in a UsualCare Setting: Retrospective Database Analysis Over 3 Years After Treatment Initiation in Health Maintenance Organization Enrollees with Dyslipidemia. Clin Ther. 2005. 27:1639-46.

13. Choi KS, Kwon SU, and Kim JS. Compliance with Risk Factor Modification: Early-Onset Versus Late-Onset Stroke Patients. Eur Neurol. 2005. 54:204-211.

14.Lindberg M, Ekstrom T, and Moller M. Asthma care and factors affecting medication compliance: the patient's point of view. Int $J$ Qual Health Care. 2001. 13:375-83

15.Borghi C, Veronessi $M$, Dormi A, Prandin $M G$, Cosentino E, and Strocchi E. Persistence of Treatment and Blood Pressure Control in Elderly
Hypertensive Patients Treated With Different Classes of Antihypertensive Drugs. Am J Ger Cardiol. 2007. 16(5): 280-6.

16.Iskedjian M, Einarson TR, MacKeigan LD. Relationship between daily dose frequency and adherence to antihypertensive pharmacotherapy: evidence from a meta-analysis. Clin Ther. 2002. 24: 302-16.

17. Vink NM, Klungel OH, stolk RP and Denig P. Comparison of Various Measures for Assessing Medication Refill Adherence Using Prescription Data. Pharmacoepidemiol Drug Saf. 2009. 18: 159-65.

18.Simon NF, Bennet K and Feely J. A review of studies of adherence with antihypertensive drugs using prescription databases. Therapeutics and Clinical Risk Management. 2005. 1(2): 93-106.

19. Shah NR, Hirsch AG, Zacker C, Wood GC, Schoenthaler A, Ogedegbe G, and Stewart WF. Predictors of First-Fill Adherence for Patients with Hypertension. Am J Hypertens. 2009. 22(4): 392-6. 